\title{
Content Production
}

14h30 - 16h00 | 31/08/2016 Wednesday | Room 17

\section{Olympic Games}

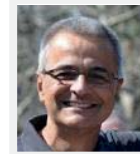

Moderator: Carlos Capellão

Director / Phase Engenharia

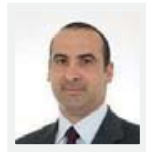

Speaker: Fernando Castelani

Engineering and Operations Director - ESPN

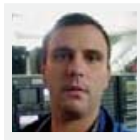

Speaker: Luis Santos

VP for Engineering and Operations - Fox Sports

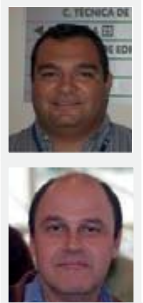

Speaker: Paulo Henrique Corona Viveiros De Castro Technology and R\&D Director - TV Globo

\section{Speaker: Lourenço Carvano}

Engineering Director - GLOBOSAT

\section{Speaker: Antonio Carlos Nobrega Sobr}

Projects and Implementation Manager - Rede Record 


\section{Content Production}

\section{Olympic Games}

\section{Moderator: CARLOS CAPELLAO}

Director - Phase Engineering

Este painel sobre a cobertura de TV dos Jogos Olímpicos Rio-2016 terá a apresentação de cinco casos, como foco nas inovações tecnológicas introduzidas na Rio-2016, as soluções encontradas para superar dificuldades e os resultados obtidos. A sessão será coroada com um debate entre os Speakers.

- Speaker: Fernando Castelani

Director de Engenharia e Operações / ESPN

- Speaker: Luis Santos

Engineering and Operations Director - ESPN

- Speaker: Paulo Henrique Corona Viveiros De Castro Technology and R\&D Director - TV Globo

- Speaker: Lourenço Carvano Engineering Director - GLOBOSAT

- Speaker: Antonio Carlos Nobrega Sobr.

Projects and Implementation Manager - Rede Record

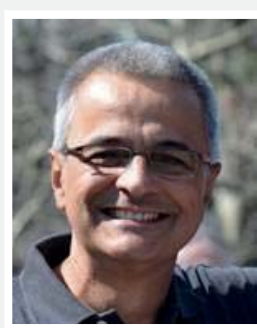

\section{CARLOS CAPELLÃO}

Director - Phase Engineering

Electronics Engineer with a degree from the UFRJ in 1974 and an MBA from FGV-

RJ.

Since 1973 he has been involved in the Television and Telecommunications industry, having worked at TV Globo, TV SBT, Radiobrás and Embratel.

Since 1980 he has managed Phase Engineering in Rio de Janeiro, working on the supply Television and Telecommunications Equipment and Systems.

Founding partner and member of the Council of Former Presidents of SET- the

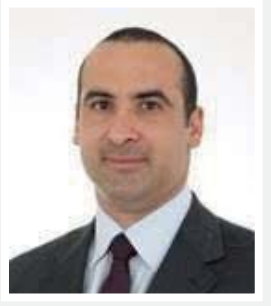
Brazilian Society of Television Engineering.

\section{FERNANDO CASTELANI}

Engineering and Operations Director - ESPN

Obtained an Engineering Degree from the University of Vale do Paraíba in 2003 and has an MBA from IBTA

His career at Harris Communications and TV Vanguarda began in 1998 

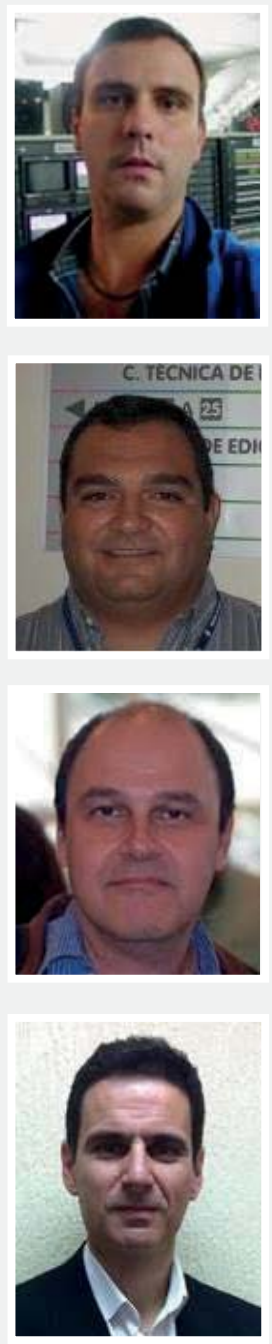

\section{LUIS SANTOS}

VP for Engineering and Operations - Fox Sports

Graduated in Electronic Engineering from Mackenzie University in 1995

His career at Casablanca/Teleimage and TVA Sistemas de Televisão began in 1995.

\section{PAULO HENRIQUE CORONA VIVEIROS DE CASTRO}

Technology and R\&D Director - TV Globo

Obtained an engineering degree in Telecommunications Engineering from PUC-Rio in $1996 \mathrm{He}$ has built his career at TV Globo since 1996.

\section{LOURENÇO CARVANO}

Engineering Director - GLOBOSAT

He has built his career at SBT, Rede Manchete and Globosat.

He was educated at the Federal Technical School of Rio de Janeiro and also studied at the School of Engineering of the UFRJ.

His career includes TV Record, Rede Manchete and Globosat, since the latter was founded 25 years ago. He has headed up several projects, including setting up the headquarters of Globosat in the Barra da Tijuca district of Rio de Janeiro, in addition to covering several international events.

\section{ANTONIO CARLOS NOBREGA SOBR.}

Projects and Implementation Manager - Rede Record

Electrical Engineer specializing in Telecommunication, from the University of São Judas Tadeu in 1990.

A 19-year career at SBT as Chief Technical and Operations Officer at TV RecordSP since 2004.

Oversaw several systems projects and engineering for covering sporting events, such as the Pan American games in Rio 2007, Guadalajara-2011 and Toronto-2015, as well as the London Olympic Games -2012 and Rio-2016. 